\title{
Krzysztof Nierzwicki
}

Biblioteka Uniwersytecka w Toruniu

krzysn@umk.pl

\section{0-0002-6860-1764}

https://doi.org/10.33077/uw.25448730.zbkh.2021.654

\section{Królewiecki egzemplarz De humani corporis fabrica Andreasa Vesaliusa (Bazylea 1555) w zbiorach Biblioteki Wyższego Seminarium Duchownego Metropolii Warmińskiej „Hosianum” w Olsztynie}

\author{
A copy of De humani corporis fabrica by Andreas Vesalius (Basel \\ 1555) in Królewiec in the collection of the Library of the Theological \\ Seminary of the Warmia Metropolis "Hosianum" in Olsztyn
}

\begin{abstract}
The author made an attempt to analyse the origin of the book De humani corporis fabrica by Andreas Vesalius (Basel 1555) from the Library of the Theological Seminary of the Warmia Metropolis "Hosianum" in Olsztyn. In the course of research it was found that the volume belonged to Johann Zell (dates of life unknown) from Cologne and his son Heinrich Zell (1518-1564). Heinrich Zell was a librarian at the Prince Albrecht's Castle Library in Königsberg. The book was then transferred to the Castle Library. In 1827, the book was placed in Königlicheund Universitätsbibliothek in Królewiec. This library changed its name in 1918 to Staats- und Universitätsbibliothek Königsberg. After World War II, the book was placed in the Library of the Seminary in Olsztyn. The copy is in good condition. It was bound in the bookbinding workshop of Kasper Angler in Królewiec around 1560.
\end{abstract}

Keywords: Olsztyn, Library of the Theological Seminary of the Warmia Metropolis „Hosianum“; Königsberg, Staats- und Universitätsbibliothek; Königsberg, Königliche- und Universitätsbibliothek; Königsberg, Schloßbibliothek; Johannes Zell; Heinrich Zell (15181564); Andreas Vesalius (1514-1564); Kaliningrad, Russia.

Słowa kluczowe: Olsztyn, Biblioteka Wyższego Seminarium Duchownego Metropolii Warmińskiej „Hosianum”; Königsberg, Staats- und Universitätsbibliothek; Königsberg, Königliche- und Universitätsbibliothek; Königsberg, Schloßbibliothek; Johannes Zell; Heinrich Zell (1518-1564); Andreas Vesalius (1514-1564); Kaliningrad, Rosja. 
Dwukrotnie, w 1543 i 1555 r. za życia Andreasa Vesaliusa (1514-1564) i pod jego nadzorem w znakomitej oficynie typograficznej Johannesa Oporinusa w Bazylei ukazało się największe z jego dzieł De humani corporis fabrica - ogromny, rewolucyjny zarówno w warstwie treściowej, jak i ilustracyjnej traktat o anatomii człowieka. W odstępie 12 lat uczony brukselczyk wespół z królem typografów bazylejskich zaopatrzył europejski rynek prawdopodobnie w około 1400 woluminów ${ }^{2}$ - niemającego sobie równych - podręcznika prężnie wówczas rozwijającej się medycyny, a szczególnie anatomii. Spośród ponad 700 zachowanych do dziś woluminów tego nadzwyczajnego dzieła ${ }^{3}$, jakie zarejestrowali trzej amerykańscy badacze Dániel Margócsy, Mark Somos i Stephen N. Joffe w obszernym dziele The Fabrica of Andreas Vesalius. A Worldwide Census, Ownership, and Annotations of the 1543 and 1555 Editions - 19 egzemplarzy znajduje się w zbiorach bibliotek współczesnej Rzeczpospolitej ${ }^{4}$. Mowa tutaj o dwóch egzemplarzach pierwszego wydania (Bazylea 1543) i 17 egzemplarzach wydania drugiego (Bazylea 1555), rozlokowanych w dziesięciu miastach Polski w 13 bibliotekach. W tej liczbie dwa egzemplarze wydania drugiego przechowuje Biblioteka Wyższego Seminarium Duchownego Metropolii Warmińskiej „Hosianum” w Olsztynie ${ }^{5}$, spośród których jeden odznacza się szczególnie ciekawą proweniencją ${ }^{6}$.

Prześledzenie drogi, jaką odbył on od chwili opuszczenia pras bazylejskiego typografa J. Oporinusa, aż do momentu, kiedy spoczął w magazynie seminaryjnej książnicy w Olsztynie, będzie zasadniczym obszarem badań, których wyniki zostaną zaprezentowane w niniejszym tekście. W ten sposób autor pragnie podjąć próbę interpretacji źródeł w kontekście oceny recepcji osiągnięć naukowych słynnego XVI-wiecznego anatoma A. Vesaliusa na dawnym i współczesnym obszarze Rzeczypospolitej. Problematyka losów wszystkich zachowanych w Polsce egzemplarzy jego największej pracy do tej pory

1 A. Vesalius, De Humani Corporis Fabrica Libri septem, Basileae, ex officina Joannis Oporini, 1543; ed. 2 1555; Obszerny biogram A. Vesaliusa i najnowszą literaturę zob. V. Nutton, Historical introduction, [in:], Vesalius, The fabric of the human body: an annotated translation of the 1543 and 1555 editions, by Daniel H. Garrison, Malcolm H. Hast, Basel 2014, s. LXXV-CIII.

2 D. Margócsy, M. Somos, S.N. Joffe, The Fabrica of Andreas Vesalius. A Worldwide Descriptive Census, Ownership, and Annotations oft he 1543 and 1555 editions, Leiden, Boston, 2018 (Medieval and Early Modern Philosophy and Science, vol. 28), (dalej Fabrica Census), s. 9.

3 Tamże, s. 8.

4 K. Nierzwicki, Warszawski egzemplarz „De humani corporis fabrica” Andreasa Vesaliusa (Bazylea 1555) ze zbiorów Biblioteki Narodowej : przyczynek do dziejów recepcji anatomii wesaliańskiej w Polsce, [w:] Dawnych ksiag niesyty : tom studiów dedykowanych Profesorowi Januszowi Tondelowi na siedemdziesięciolecie urodzin, pod red. I. Imańskiej i A. Wagnera, Toruń 2016, s. 167203; Fabrica Census, s. 202-203, 355-365.

5 Sygn.: Sd 670; Sd. 923; zob. J. Wojtkowski, Katalog druków XVI wieku Biblioteki Wyższego Seminarium Duchownego Metropolii Warmińskiej „Hosianum” w Olsztynie, Lublin 2012, s. 685.

6 Mowa o woluminie Sd 670. 
cieszyła się niewielkim zainteresowaniem. Pierwszą większą pracę na ten temat opublikowali Dorota Sidorowicz-Mulak i Arkadiusz Wagner, omawiając egzemplarz pierwszego wydania (1543) z wrocławskiego Ossolineum ${ }^{7}$. Trzy inne tomy - tym razem najpierw z Biblioteki Narodowej ${ }^{8}$, kolejno zaś z Biblioteki Uniwersyteckiej w Toruniu9 ${ }^{9}$ a w końcu z Biblioteki Gdańskiej Polskiej Akademii Nauk ${ }^{10}$ - poddał analizie piszący te słowa w latach 2016-2019. Kwestię oprawy egzemplarza z Biblioteki Elbląskiej omówiła znawczyni problematyki tegumentologicznej Ewa Chlebus ${ }^{11}$. Cały czas zatem pozostaje w tej materii wiele do zrobienia, niewątpliwie zaś przynajmniej część z zachowanych w Polsce egzemplarzy absolutnie zasługuje na szersze opracowanie naukowe. Tak jest i w wypadku będącego przedmiotem niniejszej analizy tomu z biblioteki w Olsztynie.

Kompletny egzemplarz, oprawny w skórę świńską na desce ze ślepo tłoczoną dekoracją, trafił do tego miasta z zasobów Biblioteki Uniwersyteckiej w Królewcu, o czym świadczy odciśnięta czarnym tuszem pieczęć z kursywnym tekstem Zur Universitäts Bibl., umieszczona u dołu karty frontyspisowej, poniżej typograficznego adresu wydawniczego dzieła. Wcześniej egzemplarz ten znajdował się najpewniej w tzw. Bibliotece Zamkowej (Bibliotheca Nova) księcia Albrechta Hohenzollerna na zamku w Królewcu, by po połączeniu jej z biblioteką uniwersytecką w 1827 r. zasilić zbiory tej ostatniej ${ }^{12}$.

Zanim jednak opasły tom Vesaliusa znalazł się w królewieckich zbiorach, znajdował się w rękach przynajmniej dwóch osób - Johannesa (Joannesa) Zeliusa (Zaeliusa, Zell), a następnie jego syna. Dowodzi tego zapiska proweniencyjna dwóch rąk umieszczona w górnej części karty frontyspisowej, w winiecie, pod informacjami o autorze i tytule dzieła w brzmieniu: Joannes Zaelius oraz drugą ręką: Nunc filij. Być może proweniencyjna notka Zelliusów miała swoją kontynuację, bowiem u dołu karty widnieje ślad wytartej, bliżej nieokreślonej kolejnej zapiski, niestety zupełnie dziś nieczytelnej. Ksiądz Tomasz Garwoliński - badacz dziejów książnicy seminaryjnej w Olsztynie - w swym

7 D. Sidorowicz-Mulak, A. Wagner, Dzieło Vesaliusa w oprawie Mistrza Dawida a problem początków księgozbioru króla Zygmunta Augusta, „Roczniki Biblioteczne” 2015, R. 59, s. 3-24.

8 K. Nierzwicki, dz. cyt., s. 167-203.

9 Tegoż, Chetmiński egzemplarz „De humani corporis fabrica” Andreasa Vesaliusa (Bazylea 1555) w zbiorach Biblioteki Uniwersyteckiej w Toruniu, [w:] W świecie bibliologii i informatologii. Księga dedykowana Profesor Bronisławie Woźniczce-Paruzel w 70. rocznicę urodzin, Torun 2019, s. [59]-98.

10 Tegoż, W poszukiwaniu anatomicznego traktatu De humani corporis Fabrica Andreasa Vesaliusa (Basel 1543, 1555) w Gdańsku, „Biblioteka” 2019, nr 23 (32), s. 167-207.

11 E. Chlebus, Dwie oprawy Tomasza Krügera z księgozbioru elblaskiego patrycjusza Andrzeja Morenberga, [w:] Dawnych ksiag niesyty..., s. 205-221.

12 E. Kuhnert, Geschichte der Staats- und Universitätsbibliothek zu Königsberg. Von ihre Begründung bis zum Jahre 1810, Leipzig 1926, s. 245-250; J. Tondel, Biblioteka Zamkowa (1529-1568) księcia Albrechta Pruskiego w Królewcu, Toruń 1992, s. 184-185. 
artykule zamieszczonym w Forum Bibliotek Medycznych identyfikuje tę postać, jako Jana Zeliusa $z$ Królewca, co wydaje się tropem właściwym ${ }^{13}$ i zostanie wykazane w dalszej części artykułu. Trudno bowiem uznać za zasadne - w ślad za wspomnianymi amerykańskimi badaczami - że właścicielem kodeksu był Siedmiogrodzianin z Braszowa - prawdopodobnie lekarz - Johannes Zelius ${ }^{14}$, którego - w świetle badań oraz dostępnej literatury - z właścicielem Fabrica (poza nazwiskiem) nic nie łączyło ${ }^{15}$. Przyjmując, zresztą słusznie, założenie, że właścicielem kodeksu mógł być przedstawiciel środowiska medycznego o tym nazwisku, można by sięgnąć po przynajmniej jeszcze jedną postać. Mowa tutaj o Janie Zeliusie (Joannes Zelius Troianus Francus), autorze wierszowanego utworu (pieśni) Lectori Benevolo, który poprzedza tekst dzieła bizantyjskiego lekarza Theophanesa Nonnusa De omnium particularium morborum curatione ... liber, wydanego przez Jeremiasza Martiusa, drukowanego w $1568 \mathrm{r}$. w Strasburgu w oficynie Theodosiusa Richeliusa ${ }^{16}$. Jednakże powiązanie go

13 T. Garwoliński, Druki medyczne z XV i XVI wieku w zbiorach Biblioteki Wyższego Seminarium Duchownego Metropolii Warmińskiej „Hosianum” w Olsztynie, „Forum Bibliotek Medycznych" 2017, R. 10, nr 1(19), s. 276.

14 Fabrica Census, s. 359.

15 Johanes Zelius Coronensis, pochodził - jak wspomniano - z Siedmiogrodzkiego Braszowa (Brasov, Krönstadt). 17 XI 1595 r. wstąpił na uniwersytet we Frankfurcie nad Odrą, zaś w latach 1598-1600 pełnił funkcję 31. rektora Gimnazjum Akademickiego w swym rodzinnym mieście. Zmarł 24 IV 1602 r. Niewiele możemy powiedzieć o jego księgozbiorze, ale wiemy, że posiadał w swych zbiorach przynajmniej jeszcze jeden druk, który obecnie znajduje się w Bibliotece Teleki-Bolyai (Bibliotheca Telekiana) w historycznym mieście Târgu Mureș w Transylwanii w Rumunii. Jest to Adagiorum ... epitome Erazma z Rotterdamu, w edycji Krzysztofa Plantina z 1564 r., które Zelius nabył w 1598 r. Porównanie zapisek proweniencyjnych w egzemplarzu z Târgu Mureş oraz z Olsztyna, wskazuje z całą pewnością, że właściciel druku Erazma i posiadacz omawianego woluminu Fabrica Vesaliusa, to kompletnie różne osoby. Najszersze wiadomości o nim zob. M. Szabó, S. Tonk, Erdélyiek egyetemjárása a korai újkorban 1521-1700, (Fontes Rerum Scholasticarum, IV), Szeged 1992, s. 107 poz. 1115; O jego studiach zob. Aeltere Universitäts-Matrikeln. I. Universität Frankfurt a. O., Hrsg. E. Friedländer; Mitw. G.H.T. Liebe, E. Theuner, (Publicationen aus den K. Preußischen Staatsarchiven), Bd. 1, Leipzig 1887, s. 399; F. Schullerus, Siebenbürger Studirende (sic!) an der Universität Frankfurt an der Oder, [in:] „Archiv des Vereines für Siebenbürgische Landeskunde", Neue Folge, Bd. 22, Hermannstadt 1889, s. 406; jako rektor wymieniany jest m.in. w: J. Dück, Geschichte des Kronstädter Gymnasiums. Eine Festgabe zur dritten Säcularfeier desselben, Krönstadt 1845, s. 147; Liceul Honterus. Anuar 2015/2016, red. H. Wagner, Braşov 2016, s. 14; zachowany egzemplarz z jego biblioteki wykazuje: Catalogus Librorum Sedecimo Saeculo Impressorum Bibliothecae Teleki-Bolyai Nóvum Forum Siculorum, red. M. Spielmann-Sebestyén, L. Balázs, H. Ambrus, O. Mesaros, (Biblioteca Judeţeană Mureş), Târgu Mureş 2001, s. 253; Fotografie zapisek z egzemplarza z Biblioteki Teleki-Bolyai, otrzymałem dzięki uprzejmości Pani Réka Bányai z tamtejszej biblioteki, której chciałbym tą drogą bardzo serdecznie podziękować.

16 Theophanes Nonnus, Noni Medici Clarissimi De omnivm Particvlarivm Morborvm Cvratione, sic ut Febres quoque [et] Tumores prceter naturam complectatur, Liber..., Argentorati, Excudebat Iosias Rihelius, 1568, s. [21-23] ; zob. VD16 N 1839 [online] http:/gateway-bayern.de/ VD16+N+1839 [dostęp 8.02.2021]; Pod wspomnianym utworem znajdujemy podpis Ioan. Zelius Troianus Francus; Trudno powiedzieć, czy ów Zelius był tylko poetą, czy może też lekarzem. Wiadomo jedynie, że 26 II 1563 r. wstąpił na uniwersytet w Heidelbergu; por. Die Matrikel der Uni- 
z omawianym dziełem Vesaliusa, a następnie z Królewcem wydaje się równie mało prawdopodobne, jak i w przypadku wspomnianego wyżej Siedmiogrodzianina. Biorąc zresztą pod uwagę liczne oboczności zapisu nazwiska Zelius (Zell, Zeel, Zellius, Zaelius, Cellius $)^{17}$ prawdopodobnie znalazłoby się jeszcze wiele innych postaci świata medycyny, mających potencjalne związki z poszukiwanym przez nas właścicielem przechowywanego w Olsztynie druku Fabrica.

Wychodząc z założenia, iż pierwotnym właścicielem książki był Johannes Zelius, kolejno zaś jego syn, po czym dzieło trafiło do Biblioteki Zamkowej księcia Albrechta Hohenzollerna, a w końcu do królewieckiej biblioteki uniwersyteckiej, stamtąd zaś do Olsztyna, należy w takim ciągu chronologicznym przeanalizować jego pochodzenie i losy. Warto jednak w tym miejscu zaznaczyć, że ponieważ nie wszystkie informacje - zwłaszcza z początkowego okresu dziejów opisywanego woluminu - dają się precyzyjnie udokumentować źródłowo, istnieje prawdopodobieństwo nieco innej drogi, jaką odbył bazylejski druk, zanim znalazł się w miejscu swego obecnego przechowywania. Biorąc jednakże pod uwagę dostępne źródła i literaturę, a przy tym szczególnie - w ślad za nimi - logicznie układające się następstwo zdarzeń i związanych z nimi postaci, wydaje się że zaprezentowane w niniejszym przyczynku losy olsztyńskiego egzemplarza Fabrica można uznać za wysoce prawdopodobne.

Kim zatem jest ów Joannes Zelius, którego nazwisko zostało uwiecznione na frontyspisie dzieła Vesaliusa? Można z dużą dozą prawdopodobieństwa przyjąć, że - o ile był on pierwszym posiadaczem woluminu (a na to wszystko wskazuje) - musiał być związany bezpośrednio, lub poprzez swojego syna z Królewcem. Wniosek taki wysnuć można nie tylko z faktu, iż dzieło to znalazło się z czasem w zbiorach dwóch królewieckich bibliotek, ale również dlatego, że okrywającą je oprawę wykonano właśnie w grodzie nad Pregołą, w działającej na użytek dworu książęcego pracowni introligatorskiej Kaspra Anglera $^{18}$. Dowodzi to jednoznacznie, że swe czytelnicze życie wolumin Vesaliusa rozpoczął właśnie w Królewcu, tym samym zaś jego pierwszy właściciel był niewątpliwie związany z tym miastem.

Wszystko wskazuje więc na to, że mowa w tym wypadku o pochodzącym z Kolonii, ojcu przyszłego bibliotekarza królewieckiej Biblioteki Zamkowej,

versität Heidelberg von 1386 bis 1662, Hrsg. G. Toepke, T. 2 1554-1662, Heidelberg 1886, s. 31. (tu określony jako Joannes Zeul, Troianus Francus).

17 Kilka obocznych sformułowań nazwiska Zell, w odniesiniu do Heinricha Zella - bibliotekarza królewieckiej Biblioteki Zamkowej ks. Albrechta Hohenzollerna podaje J. Tondel, dz. cyt., s. [47]; oraz K. H. Burmeister, Der Kartograph Heinrich Zell (1518-1564), [in:] Science and history. Studies in honor of Edward Rosen, Wrocław 1978, (Studia Copernicana 16), s. [427].

$18 \mathrm{O}$ tym fakcie szerzej w dalszej części tekstu. 
kartografa Heinricha Zella - Johannesie Zellu ${ }^{19}$. Johannes był jedynym znanym historykom dzieckiem pierwszego drukarza kolońskiego Ulricha Zella i poślubionej przez niego w $1471 \mathrm{r}$. Katarzyny (Katharina) Spangenberg ${ }^{20}$. Nie znamy niestety precyzyjnej daty jego urodzin. Historycy - w ślad za źródłami uniwersyteckimi - utrzymują jedynie, że 19 I 1488 r., nie mając jeszcze 14 lat, wstąpił na uniwersytet w Kolonii ${ }^{21}$, studiując tam w czasach, kiedy rektorem był znakomity teolog Gerardus de Harderwyk ${ }^{22}$. Według XIX-wiecznego badacza niemieckiego Johanna Jacoba Merlo, Johann był dwukrotnie żonaty, pierwszy raz ze Styngen Monnekop (Christine Mohnkopf), drugi raz z Johanną, z którą miał trzy córki Katarzynę, Annę i Elżbietę. Ostatnia z żon miała go przeżyć, by już w 1544 r. w źródłach archiwalnych występować jako wdowa ${ }^{23}$. W innej XIX-wiecznej publikacji odnoszącej się do historii Kolonii, Johann Zell jest czynny jeszcze w $1575 \mathrm{r}^{24}$, chociaż wydaje się to mało prawdopodobne, chyba że mamy do czynienia z kolejnym - nie znanym nam - przedstawicielem rodziny Zellów o imieniu Johann ${ }^{25}$. Obie publikacje nic nie wspominają o męskim potomku Johanna - Heinrichu. Bacząc zatem na te rozbieżności i nieprecyzyjność źródeł ${ }^{26}$, zgodzić się chyba należy ze współczesnym badaczem Karlem Heinzem Burmeistrem, który - w publikacji poświęconej Heinrichowi Zellowi - konstatuje, iż wprawdzie niepodważalnym jest pochodzenie Heinricha z drukarskiej rodziny Zellów, niemniej jednak nie udaje się tego potwierdzić w źródłach genealogicznych ${ }^{27}$.

Trudno również jednoznacznie sprecyzować, czym trudnił się Johannes Zell. Przypuszczalnie pracował czas jakiś w przedsiębiorstwie drukarskim ojca $^{28}$, był wszakże jedynym jego spadkobiercą. Jego postać określana jest

19 J. Tondel, dz. cyt., s. 48.

20 K.H. Burmeister, dz. cyt., s. 428; J.J. Merlo, Ulrich Zell Koelns erster Drucker, Bearb. O. Zaretzky, Koeln 1900, s. 25.

21 Die Matrikel der Universität Köln, Bearb. H. Keusen, Bd. 2 (1476-1559), Hanstein, Bonn 1919, s. 230 (Ulrici impressoris minorennis ad artes non iuravit et solvit); J.J. Merlo, dz. cyt., s. 25.

22 H. Reusch, Harderwyk, Gerhard von, [in:] Allgemeine Deutsche Biographie 10 (1879), s. 593, [online] https://www.deutsche-biographie.de/pnd100965555.html\#adbcontent [dostęp: 20.01.2021].

23 J.J. Merlo, dz. cyt., s. 25; tegoż, Die Meister der altkölnischen Malerschule, Köln 1852, s. 93.

24 Köln und Bonn mit ihren Umgebungen. Für Fremde und Einheimische. Aus den besten, und vorzüglich aus noch unbenutzten Quellen bearbeitet. Mit einem Grundrisse von Köln, Köln 1828, s. 50 .

25 Wiele wątpliwości co do identyfikacji osób noszących nazwisko Zell pochodzących również z okolic Kolonii zgłasza cytowany już K.H. Burmeister, zob. dz. cyt., s. 442.

26 Być może właśnie zapiska proweniencyjna położona na karcie tytułowej opisywanego druku Vesaliusa jest kolejnym źródłem potwierdzającym związek rodzinny Johanna Zella z Heinrichem. Wszakże w niej wyraźnie zaakcentowano relację: ojciec-syn.

27 K.H. Burmeister, dz. cyt., s. 428.

28 Tamże. 
niekiedy w dawnych publikacjach niemieckich jako Meister Johann Zell, co mogłoby sugerować, iż rzeczywiście parał się jakimś rzemieślnictwem ${ }^{29}$. Nietrudno również ocenić możliwości finansowe Johanna, a co za tym idzie ustalić, na ile był w stanie poczynić tak kosztowny zakup, jakim była Fabrica Vesaliusa $^{30}$. W literaturze - powołującej się na źródła archiwalne - jest sporo informacji o rozlicznych nieruchomościach będących w posiadaniu rodziny i interesach prowadzonych przez jego ojca, a także pokaźnym majątku który Johann odziedziczył po jego śmierci ${ }^{31}$. Można zatem przyjąć, że wydatek na książkę, zwłaszcza dla obytego $\mathrm{z}$ handlem księgarskim drukarza, był w zasięgu jego możliwości. Prawdopodobnie Johann Zell nabył tom Fabrica z przeznaczeniem dla swojego syna, który miał objąć niebawem posadę na dworze księcia Albrechta w Królewcu. Może cenny kodeks był zaplanowany jako dar dla którejś z książęcych bibliotek, zaś przedsiębiorczy ojciec chciał w ten sposób zjednać względy dla swego syna u jego nowego pracodawcy. Nie wydaje się bowiem, aby druk na dłużej pozostawał w rękach Johanna, skoro nieoprawny trafił niebawem po zakupie do odległego Królewca. Niestety na tym etapie badań precyzyjne rozstrzygnięcie tej kwestii nie będzie możliwe.

Niezależnie od tych wątpliwości, wiemy że drugim właścicielem prezentowanego dzieła Vesaliusa, po Johannie Zellu stał się jego syn Heinrich. Postać Heinricha Zella jest doskonale znana i opisana przez wielu badaczy ${ }^{32}$, zatem w tym miejscu ograniczymy się do podstawowych informacji z jego życiorysu. Heinrich - jak już wspomniano - urodził się w Kolonii w $1518 \mathrm{r}$. Według przywoływanego już K.H. Burmeistra, data ta - na tle wielu innych niepewnych informacji odnoszących się do jego pochodzenia - nie budzi wątpliwości, bowiem rok swego urodzenia Heinrich potwierdził osobiście, przy okazji wykonanej przez siebie restauracji globusa w 1549 r., przedstawiając siebie wówczas jako 31-latka ${ }^{33}$. Przyszły królewiecki bibliotekarz studia podjął najpierw na uniwersytecie w Bazylei, a po kilku latach kontynuowal je w Wittenberdze, choć nie uwieńczył swej edukacji dyplomem. Specjalizował się w geografii, historii i astronomii, pozostawiwszy po sobie kilka prac głównie kartograficznych, spośród których szczególny rozgłos zapewniła mu, wydrukowana w 1542 r. u jego krewnych w Norymberdze mapa Descriptio Prusiae. Przede wszystkim temu właśnie dziełu miał zawdzięczać swą karierę królewieckiego bibliotekarza. Już jako książęcy opiekun librarii zamkowej, Zell napisał dzieło

29 J.J. Merlo, dz. cyt., s. 93;

30 Koszt zakupu wahał się pomiędzy 4 a 8 florenami, zob. Fabrica Census, s. 13.

31 J.J. Merlo, dz. cyt., passim.

32 Zob. przede wszystkim K.H. Burmeister, dz. cyt., passim; A. Kolb, Der Kartograph Heinrich Zell. Ein unbekannter Strassburger Drucker des 16. Jahrhunderts, „Gutenberg-Jahrbuch” 1972, s. 174-177.

33 K.H. Burmeister, dz. cyt., s. 428. 
historyczno-genealogiczne poświęcone swemu protektorowi, które wydrukował królewiecki typograf Heinrich Daubmann ${ }^{34}$. W swojej zawodowej karierze Heinrich Zell trudnił się również drukarstwem, co nie wydaje się być dziwnym, zważywszy na jego rodzinne związki z czarną sztuką. Jako dwudziestokilkulatek parał się także dydaktyką szkolną, ucząc w latach 1537-1538 w łacińskiej szkole w Strasburgu ${ }^{35}$.

Zanim Heinrich objął posadę książęcego bibliotekarza w Królewcu (1557 r.), 4 IX 1555 r. zapisał się na Albertynę, zaś w matrykułach uniwersyteckich odnotowano go jako „Heinricus Czeel” „mathematicus excellens et cosmographus" ${ }^{36}$. W tym samym czasie został jednocześnie przyjęty na służbę do księcia, choć nieznana jest jego ówczesna pozycja. Otrzymał wówczas uposażenie w wysokości 30 marek (grzywien). Dwa lata później objął stanowisko bibliotekarza, a jego pensja roczna wzrosła do 40 marek $^{37}$. Wysokie umiejętności bibliotekarskie, które zaowocowały znaczącym uzupełnieniem księgozbioru oraz ponownym (po jednym ze swych poprzedników - Polyphemie) rzeczowym skatalogowaniem zbiorów, a także wprowadzeniem w użytkowanie ekslibrisu, który pomagał w zabezpieczeniu książek, plasowały go w gronie najlepszych, jeśli nie najlepszego z królewieckich bibliotekarzy pierwszych dziesięcioleci istnienia Biblioteki Zamkowej ${ }^{38}$. Do jego ważnych bibliotekarskich osiągnieć należało również spisanie znaczącej, liczącej blisko pół tysiąca tomów biblioteki znakomitego teologa protestanckiego Johannesa Poliandra (Graumann), która stała się podstawą późniejszej Biblioteki Miejskiej Królewca ${ }^{39}$. Bibliotekarska kariera H. Zella została przerwana wraz z jego śmiercią w $1564 \mathrm{r}$.

Czy nieoprawny blok opasłej książki Vesaliusa Zell przywiózł ze sobą, przybywszy jesienią $1555 \mathrm{r}$. do Królewca, czy też został mu przesłany np. przez ojca z Kolonii, dziś tego już nie uda się rozstrzygnąć. Przywoływany wielokrotnie Janusz Tondel, autor obszernej pracy o Bibliotece Zamkowej, uważa, że kłopoty z transportem nie pozwoliły Zellowi zabrać do Królewca własnych

34 J. Tondel, dz. cyt., s. 51.

35 K.H. Burmeister, dz. cyt., s. 431-432; J. Tondel, dz. cyt., s. 54.

36 Die Matrikel und die Promotionsverzeichnisse der Albertus-Universität zu Königsberg i. Pr. 1544-1829. Bd. 1, Die Immatrikulationen von 1544-1656, Hrsg. G. Erler, Bd. I, Leipzig 1910, s. 19; K.H. Burmeister, dz. cyt., s. 441.

37 K.H. Burmeister, dz. cyt., s. 428; J. Tondel, dz. cyt., s. 65.

38 J. Tondel, dz. cyt., s. 71; tegoż, Ekslibrisy Biblioteki Zamkowej Księcia Albrechta, [w:] Ksią̇ka w dawnym Królewcu Pruskim, Torun 2001, s. 265.

39 Katalog ten zatytułowany Catalogus librorum qui conseruantur in Bibliotheca Ecclesiae parochialis veteris urbis Regiomontanae ex Testamente Reuerend: D. Joannis Poliandri vel Grauman Anno 1560 conscriptus ab illustriss. Principis Alberti Borussorum Ducis bibliothecario Henricho Zellio Agrippinate został wydany przez Ch. Krollmanna, zob. Geschichte der Stadtbibliothek zu Königsberg. Mit einem Anhang Katalog der Bibliothek des M. Johannes Poliander 1560, Hrsg. Ch. Krollmann, Königsberg 1929, s. 1-66. 
książek, z których znamy dwa woluminy przechowywane dziś w Leopold-Sophien-Bibliothek $\mathrm{w}$ niemieckim mieście Überlingen ${ }^{40}$. Z drugiej strony Oporinus zakończył druk Fabrica w sierpniu 1555 r. $^{41}$, a zatem mało prawdopodobnym jest, aby już we wrześniu znajdował się on w rękach Zellów. Możliwe zatem, że egzemplarz Vesaliusa dotarł do Królewca nieco później, w chwili kiedy Heinrich piastował, lub obejmował którąś ze swych posad na książęcym dworze.

Zastanówmy się zatem czy to $\mathrm{H}$. Zell przekazał wspaniały tom do Biblioteki Zamkowej i kiedy faktycznie znalazł się on na półkach tej książnicy. Istnieje pewna wątpliwość w tej materii. Otóż wiemy bezsprzecznie, że objąwszy w 1557 r. posadę książęcego bibliotekarza, H. Zell przystąpił do intensywnych prac nad porządkowaniem księgozbioru. W tym celu sporządził nowy katalog zbiorów, a w konsekwencji tego zaopatrzył wszystkie książki w charakterystyczną, sporządzoną starannym kaligraficznym pismem sygnaturę, którą lokował na górnym marginesie karty tytułowej ${ }^{42}$. Tak jednak nie postąpił z bazylejskim drukiem Vesaliusa. Nie wyposażył go też w okazały ekslibris, zwyczajowo naklejany na odwrocie wierzchniej okładziny, który wyszedł z użytku po jego śmierci43. Nie zmienia to faktu, że książka jednak znalazła się w bibliotece zamkowej. Ewidentnie wskazuje na to charakterystyczna dla wielu królewieckich tomów sygnatura. Nie wyszła ona jednak spod ręki Zella. Sposób jej umieszczenia i zapis wskazują, że jej twórcą był najpewniej Michael Scrinius, jeden z kolejnych bibliotekarzy zamkowych działający już po śmierci H. Zella w latach 1567-1585 ${ }^{44}$. Identyczny sposób sygnowania odnajdujemy również na szeregu woluminów pochodzących z tego znaczącego księgozbioru, przechowywanych w Bibliotece Uniwersyteckiej w Toruniu ${ }^{45}$. Jak zatem wythumaczyć tę sytuację. Być może Zell - zostawszy opiekunem zamkowej książnicy - skonstatował, że w jej zbiorach znajduje się już wolumin pracy Vesaliusa w edycji z 1543 r wraz z jego skrótem Epitome ${ }^{46}$. Zapewne w związku z tym nie spieszył się z jej włączeniem do księgozbioru, a oddał np. w użytkowanie

$40 \quad$ J. Tondel, Biblioteka Zamkowa ..., s. 66.

$41 \mathrm{Ph}$. Oldfield, Vesalius at 500, an exibition commemorating the five-hundredth anniversary of the birth of Andreas Vesalius, Toronto 2014, s. 61.

42 J. Tondel, Królewiecki egzemplarz dzieła Mikołaja Kopernika „De revolutionibus“ (Norymberga 1543) ze zbiorów Biblioteki Uniwersyteckiej w Toruniu, [w:] tegoż, Ksiązka ..., s. 31; tegoż, Katalog Poloników Kammerbibliothek i Nova Bibliotheca księcia Albrechta Pruskiego zachowanych w zbiorach Biblioteki Uniwersyteckiej w Toruniu, Toruń 1991, s. V.

43 J. Tondel, Biblioteka Zamkowa ..., s. 105-106; Tegoż, Ekslibrisy Biblioteki Zamkowej..., s. 265 .

44 E. Kuhnert, dz. cyt., s. 81; J. Tondel, Katalog poloników..., dz. cyt., s. V.

45 BUT np. Ob. 6. IV. 66-67; Ob. 6. III. 80-81; Ob. 6. II. 1684; Ob. 6. II. 1233; Ob. 6. II. 1134-1135.

46 E. Kuhnert, dz. cyt., s. 29; J. Tondel, Biblioteka Zamkowa ..., s. 111. 
któremuś z książęcych lekarzy ${ }^{47}$, lub przekazał do prywatnej kolekcji księcia tzw. Kammerbibliothek ${ }^{48}$, która w 1583 r., a więc już w czasach Scriniusa, została połączona z Biblioteką Zamkową ${ }^{49}$. To thumaczyłoby brak sygnatur Zella, a obecność znaków własnościowych sporządzonych dopiero przez Scriniusa. Kwestie te będą niestety musiały pozostać nierozstrzygnięte, zwłaszcza, że nie mamy również żadnych wiadomości o prywatnym księgozbiorze Zella, które mogłyby rzucić światło na jego zainteresowania czytelnicze. Wszakże niewykluczonym jest również, że książka pozostawała w posiadaniu Zella aż do jego śmierci (1564) i dopiero po tym czasie została włączona do Biblioteki Zamkowej. Musiało się to jednak wydarzyć nie później niż w 1585 r., a więc przed śmiercią Scriniusa.

Niezależnie od tych rozważań musimy przyjąć, że w pewnym momencie wesaliuszowskie dzieło trafiło właśnie do zbiorów Biblioteki Zamkowej, często też nazywanej - dla odróżnienia od wspomnianej Kammerbibliothek - Nową Biblioteką (Bibliotheca Nova). Zamkowa libraria, zwłaszcza w odniesieniu do pierwszych kilku dziesięcioleci istnienia, doczekała się swego naukowego opracowania ${ }^{50}$. Książę Albrecht założył ją w 1529 r. obok funkcjonującego już jego prywatnego księgozbioru. W zamierzeniu fundatora miała ona stać się instytucją publiczną przeznaczoną dla królewieckiego środowiska naukowego, szczególnie dla uczonych przyszłego uniwersytetu, powołanego ostatecznie przez księcia w 1544 r. W 1534 r. książę zatrudnił do jej opieki pierwszego bibliotekarza, Felixa Königa znanego z łacińskiego przydomka - Polyphemus. Bibliotekę oficjalnie otwarto i udostępniono publiczności w 1540 r. W jej rozwoju w okresie panowania Albrechta, szczególnie zaznaczyli się dwaj bibliotekarze, wspomniani Polyphemus i H. Zell. Spod ich pióra wyszły profesjonalne katalogi biblioteczne. Oni też przyczynili się ogromnie do powiększenia księgozbioru.

47 W tym czasie książęcym lekarzem i profesorem na Albertynie był Andrzej Aurifaber, wielce zaufany księcia i miłośnik ksiąg, zob. J. Tondel, Księgozbiór królewieckiego lekarza Andrzeja Aurifabra (1513-1559), [w:] tegoż, Książka..., s. 51-129; Th. Anselmino, Medizin und Pharmazie am Hofe Herzog Albrechts von Preußen (1490-1568), Heidelberg 2003, s. 41-46, 103-106.

48 Niestety wolumin Vesaliusa nie został odnotowany w katalogu Kammerbibliothek z 1576 r. zob. P.G. Thielen, Ein Katalog der Kammerbibliothek Herzog Albrecht von Preussen aus dem Jahre 1576, ,Jahrbuch der Albertus-Universität zu Königsberg Pr.“, Bd. IV, 1954, s. 202-226.

49 Zob. A.E Walter, Das Schicksal der Königsberger Archive und Bibliotheken. Eine Zwischenbilanz, [in:] Königsberger Buch- und Bibliotheksgeschichte, Hrsg. A.E. Walter, Köln 2004, s. 7.

50 J. Tondel, Biblioteka Zamkowa ..., passim; Janusz Tondel jest autorem licznych prac poświęconych królewieckim zbiorom, m.in. wydawnictw książkowych: Eruditio et prudentia. Die Schloßbibliothek Herzog Albrechts von Preußen. Bestandkatalog 1540-1548, Wiesbaden 1998; Książa w dawnym Królewcu Pruskim, Torun 2001, a także wespół z Arkadiuszem Wagnerem The Silver Library of Duke Albrecht of Prussia and his wife Anna Maria, Berlin 2019; znaczną uwagę losom Biblioteki Zamkowej, również poza okresem życia księcia Albrechta poświęcił cytowany wielokrotnie Ernst Kuhnert, zob. tegoż, dz. cyt., passim. 
W nowym miejscu - co już sygnalizowano - Fabrica zyskała sygnaturę S 82 III, naniesioną ręką szóstego bibliotekarza tej książnicy - M. Scriniusa, który pełnił swą funkcję przez blisko 20 lat. Sygnaturę ulokował on na wystającym poza blok książki brzegu wewnętrznej strony dolnej okładziny. Powtórzono ją w górnym prawym rogu wierzchniej okładziny, chociaż jest tam mało czytelna. Sygnatura ta była odpowiednikiem opisu książki w nowym katalogu rzeczowym, sporządzonym przez Scriniusa, w którym pod majuskulną literą „S” zgrupowano opublikowane w formacie folio, łacińskie książki z zakresu medycyny ${ }^{51}$.

Opasły podręcznik brukselskiego anatoma przetrwał w zamkowej książnicy ponad 220 lat, by w 1810 r. zostać przeniesionym wraz z całym księgozbiorem do nowego budynku tzw. Könighaus przy ulicy Königstrasse, w którym ulokowano kilka innych księgozbiorów, w tym także bibliotekę uniwersytecką. W jakimś momencie, być może w wieku XVII lub XVIII, Fabrica zyskała jeszcze jedną sygnaturę - N. 41 oraz wyrażone majuskułą w skróconej formie określenie autora i tytułu dzieła VESSALII ANAT, widniejące w górnej partii wierzchniej okładziny tomu. $Z$ czasem też wolumin został ostemplowany znaną $\mathrm{z}$ wielu egzemplarzy królewieckich ${ }^{52}$ owalną pieczęcią z centralnie umieszczoną koroną i wieńcem laurowym, w której otoku widnieje napis BIBLIOTHECA REGIOMONTANA. Odbijano ją niebieskim tuszem zazwyczaj na odwrocie karty tytułowej druku ${ }^{53}$. Po raz ostatni wolumin został osygnowany tuż przed przeniesieniem zbiorów do nowej lokalizacji. Tym razem znaki własnościowe - Ea 30a Fol. naniesiono ołówkiem, starannym kaligraficznym pismem w górnej partii wyklejki wierzchniej okładziny w czasach sprawowania opieki nad biblioteką przez Georga Nicoloviusa (1809-1810). Odzwierciedlają one zapis w powstałym w tym samym czasie katalogu rzeczowym, skupiającym księgozbiór z zakresu medycyny tym razem pod literami Ea-d ${ }^{54}$. Warto może przy tej okazji dodać, iż jeszcze nieco wcześniej, mianowicie w pierwszej połowie XVIII w., w czasach, kiedy bibliotekarskie powinności w zamkowej librarii czynił profesor Johannes Behm, jej zbiory uzupełniono o kolejny egzemplarz dzieła Vesaliusa, tym razem w lejdejskiej edycji z 1725 r. ${ }^{55}$ Można

51 E. Kuhnert, dz. cyt., s. 76.

52 W toruńskiej Bibliotece Uniwersyteckiej przechowuje się obecnie 170 takich woluminów; por. J. Tondel, Biblioteka Zamkowa ..., s. 9.

53 M. Strutyńska, Struktura proweniencyjna zbioru starych druków Biblioteki Uniwersyteckiej w Toruniu. Przewodnik po zespołach. Problemy badawcze i metodologiczne, Torun 1999, s. [12]; tejże, Alte Drucke Königsberger Provenienz in den Beständen der Universitätsbibliothek Toruń, [in:] Königsberger Buch..., s. 549, 556.

54 E. Kuhnert, dz. cyt., s. 244.

55 A. Vesalius, Opera omnia anatomica \& chirurgica. Cura Hermanni Boerhaave \& Bernhardi Siegfried Albini, Lugduni Batavorum, apud Joannem du Vivie at Joan. \& Herm. Verbeek, 1725; zob. E. Kuhnert, dz. cyt., s. 175. 
zatem przyjąć, że do momentu scalenia księgozbiorów, w Bibliotece Zamkowej znajdowały się co najmniej trzy egzemplarze wielkiego anatomicznego traktatu Vesaliusa. W ciągu tych dwóch wieków istnienia interesującej nas książnicy, najaktywniejszymi jej bibliotekarzami byli wspomniani M. Scrinius, kolejno Martin Silvester Grabe (1667-1679) i Georg Nicolovius. W 1827 r. połączone księgozbiory w Könighaus zostały ostatecznie opatrzone wspólnym szyldem Königliche- und Universitätsbibliothek ${ }^{56}$. W tym okresie egzemplarz Fabrica ostemplowano wzmiankowaną już, odbitą czarnym tuszem pieczęcią z kursywnym tekstem Zur // Universitäts // Bibl. ${ }^{57}$ Skromna ta i niewyszukana $\mathrm{w}$ stylistyce pieczątka, zastosowana została prawdopodobnie właśnie w momencie scalania księgozbiorów, mając zapewne charakter pospiesznie nanoszonego inwentaryzacyjnego znaku własnościowego. W 1901 r. zbiory tej biblioteki, przemianowanej po I wojnie światowej na Staats- und Universitätsbibliothek Königsberg, zostały przeniesione $\mathrm{z}$ dotychczasowego miejsca do nowego gmachu przy ulicy Mitteltragheim 22, gdzie w liczbie około 700000 tomów przetrwały do $1944 \mathrm{r}$. Wówczas to, w obawie przed bombardowaniami aliantów, Niemcy najcenniejsze jej zbiory ukryli w kilku majątkach pruskich na Warmii i Mazurach ${ }^{58}$. Stamtąd trafiły one w głównej mierze do nowotworzonej Biblioteki Uniwersyteckiej w Toruniu ${ }^{59}$, ale także w wiele innych miejsc, w tym do Biblioteki Narodowej oraz Biblioteki Akademii Nauk w Wilnie, a także do Olsztyna, gdzie stały się elementem m.in. książnicy seminaryjnej ${ }^{60}$. Do Olsztyna trafiło również wiele źródeł archiwalnych odnoszących się do uniwersytetu w Królewcu. Dzisiaj przechowywane są w Wojewódzkim Archiwum Państwowym ${ }^{61}$.

56 J. Tondel, Biblioteka Zamkowa..., s. 184-185; M. Komorowski, Das Schicksal der Staatsund Universitätsbibliothek Königsberg, „Bibliothek. Forschung und Praxis”, R. 1980, nr 4, s. 140 (gdzie podaje datę 1828).

57 A.E. Walter, Die Königsberger Universitätsbibliothek in der Frühen Neuzeit. Grundzüge ihrer Geschichte, bibliotheksgeschichtliche Quellen, Perspektiven der Forschung, [in:] Die Universität Königsberg in der Frühen Neuzeit, Hrsg. H. Marti, M. Komorowski, Köln 2008, s. 278-279; M. Strutyńska, Struktura proweniencyjna ..., s. [12]; tejże, Alte Drucke..., s. 557.

58 Wymienia je M. Komorowski, dz. cyt., s. 145.

59 S. Burhardt, Historia pierwszego pięciolecia Biblioteki UMK, „Studia o Działalności i Zbiorach Biblioteki Uniwersytetu Mikołaja Kopernika” cz. III, Toruń 1987, s. 13-15; J. Serczyk, Suche nach Büchern im ehemaligen Süd-Ostpreussen in den ersten Jahren nach dem Zweiten Weltkrieg. Erinnerungen eines polnischen Bibliothekars, [in:] Königsberger Buch ..., s. [483]-494.

60 J. Tondel, Das Schicksal der Königsberger Schlossbibliothek, „Preussenland. Mitteilungen der Historischen Kommision für Ost- und Westpreussiche Landesforschung und aus den Archiven der Stiftung Preussischer Kulturbesitz" Jg. 25, 1987, s. 39-48; M. Komorowski, dz. cyt., s. 149; D. Bikauskienè, O. Bliūdžiūtè, Drucke Königsberger Provenienz in der Akademiebibliothek Vilnius - Das 16. Jahrhundert, [in:] Königsberger Buch..., s. [519]-546; J. Tondel, Biblioteka Zamkowa ..., s. 186.

61 H. Marti, Die Quellenbestände zur frühneuzeitlichen Königsberger Universitätsgeschichte im polnischen Olsztyn (Allenstein). Ein erster fragmentarischer Überblick, [in:] Königsberger 
Wraz z woluminem Fabrica do Biblioteki „Hosianum” trafiło jeszcze 17 innych starych druków XVI w. oraz dwa inkunabuły pochodzących z biblioteki uniwersyteckiej w Królewcu. W seminaryjnej książnicy egzemplarz Fabrica zyskał nową sygnaturę $\mathrm{Sd}$ - oznaczającą stare druki oraz numer 670 (numer inwentarzowy: 129/88). Sygnaturę umieszczono wewnątrz owalnej pieczęci z tekstem w otoku: Ex libris Bibliothecae Seminarii Warmiensis Olstini odciśniętej na odwrocie karty tytułowej. Kolejny znak własnościowy w postaci ekslibrisu widnieje na wyklejce dolnej okładziny. Jest to niewielkich rozmiarów karteczka z tekstem BIBLIOTEKA//WARMIŃSKIEGO SEMINARIUM DUCHOWNEGO //,HOSIANUM” //w Olsztynie z wpisaną weń ponownie niebieskim flamastrem sygnaturą Sd 670. Wolumin wraz z pozostałymi starodrukami w liczbie ponad 7500 tomów, w tym 324 inkunabułami, przechowywany jest w nowym gmachu bibliotecznym, funkcjonującym w tym miejscu od $1997 \mathrm{r}^{62}$ Od $2007 \mathrm{r}$. wszystkie druki zabytkowe znajdują się w odrębnym, profesjonalnie zabezpieczonym pomieszczeniu magazynowym ${ }^{63}$. Zarówno inkunabuły, jak i druki XVI w., w tym Fabrica, zostały odnotowane w publikowanych obszernych katalogach biblioteki seminaryjnej ${ }^{64}$, która doczekała się także kilku odrębnych studiów odnoszących się do jej dziejów i zasobów ${ }^{65}$. Wartym podkreślenia jest również fakt - o czym nadmieniono - iż książnica seminaryjna w Olsztynie jest posiadaczem jeszcze jednego woluminu drugiej edycji De humani corporis fabrica. Tom okryty XVI-wieczną oprawą mniszą na tekturze ze ślepo tłoczoną dekoracją zachował się w bardzo dobrej kondycji, chociaż pozbawiony jest karty tytułowej. Nie przetrwały na nim ślady dawnych właścicieli poza superekslibrisem literniczym F D T, za którym zapewne skrywa się tożsamość jego pierwszego posesora, i datą $1578^{66}$.

Buch ..., s. [571]-582; A.E. Walter, Die Königsberger Universitätsbibliothek in der Frühen Neuzeit..., s. 275 .

62 T. Garwoliński, Powojenne dzieje Biblioteki Warmińskiego Seminarium Duchownego „Hosianum” w Olsztynie, [w:] Cor Dioecesis. 450 lat Warmińskiego Seminarium Duchownego „Hosianum” (1565-2015), red. A. Kopiczko, P. Rabczyński, Olsztyn 2015, s. 492.

63 Tamże, s. 495.

64 J. Wojtkowski, dz. cyt., s. 836 (zob. Skorowidz właścicieli); J. Obłąk, Z. Jaroszewicz-Pieresławcew, J. Wojtkowski, Katalog inkunabułów Biblioteki Wyższego Seminarium Duchownego Metropolii Warmińskiej „Hosianum” w Olsztynie, Olsztyn 2007, s. 149 (zob. Właściciele inkunabułów).

65 Ograniczając się do prac współczesnego badacza dziejów biblioteki Tomasza Garwolińskiego zob. m.in. T. Garwoliński, Dzieje Biblioteki „Hosianum” (Braniewo - Olsztyn: 1565-2008), „Fides. Biuletyn Bibliotek Kościelnych” 2008, nr 1-2, s. 59-72; tegoż, Druki medyczne ..., s. 252-281; tegoż, Utracone i zachowane kościelne księgozbiory warmińskie od XVII do XX wieku, „Bibliotheca Nostra. Śląski Kwartalnik Naukowy” 2015, nr 3, s. 116-135; tegoż, 60. rocznica wznowienia powojennej działalności Biblioteki Hosianum w Olsztynie, „Fides. Biuletyn Bibliotek Kościelnych” 2009, nr 1-2 (28-29), s. [96]-115; tegoż, Charakterystyka zbioru druków z XVI wieku Biblioteki Wyższego Seminarium Duchownego Metropolii Warmińskiej „Hosianum” w Olsztynie, „Archiwa, Biblioteki i Muzea Kościelne" 2014, nr 102, s. [45]-65; tam dalsza literatura.

66 Odnotował go w swoim artykule ks. T. Garwoliński, Druki medyczne..., s. 276. 
Uzupełnieniem zagadnień proweniencyjnych w odniesieniu do omawianego egzemplarza Fabrica winien być jego szczegółowy opis fizyczny, ze szczególnym uwzględnieniem okrywającej go oprawy. Ta zaś, charakterystyczna w dekoracji dla epoki renesansu, pochodzi mniej więcej z szóstej dekady XVI w. Jak już zasygnalizowano, dzięki badaniom niemieckiego oprawoznawcy Konrada Haeblera, a wcześniej historiografa biblioteki uniwersyteckiej w Królewcu Ernsta Kuhnerta, można ją bez cienia wątpliwości przypisać działającemu w latach 1532-1565 królewieckiemu introligatorowi Kasprowi Anglerowi ${ }^{67}$, Dowodzą tego opisane w obu źródłach użyte do jej dekoracji radełka figuralne przedstawiające postacie religijnych reformatorów. Przyjrzyjmy się jej zatem szczegółowo. Składają się na nią dwie fazowane, prawdopodobnie dębowe deski obciągnięte białą skórą świńską garbowaną roślinnie. Dekorację górnej okładziny stanowią cztery tłoczone na ślepo i obwiedzione strychulcem bordiury. Patrząc od zewnątrz - pierwszą wykonano radełkiem mającym w swym rysunku przeplatające się półpierścienie i lilijki. Kolejną - najbardziej dekoracyjną, wyciśnięto również radełkiem z półpostaciami przedstawiającymi w arkadach Marcina Lutra MAR LUT (MARTINUS ?), Erazma z Rotterdamu - ERAS ROT (?), Filipa Melanchtona - PHIL MEL (?) i jeszcze jedną, trudną do identyfikacji postać, prawdopodobnie Jana Husa - JOHAN HVS (?). Niestety nieczytelny rysunek zarówno postaci, jak i części podpisów nie pozwala na dokładne określenie pozycji tego radełka w katalogu Haeblera. Trzecią bordiurę pozbawiono niemal dekoracji, gdzieniegdzie jedynie została ozdobiona drobnymi stempelkami mającymi w swym rysunku liść i kwiatek. Ostatnia, która precyzyjnie pozwala zidentyfikować oprawę jako dzieło królewieckiego mistrza Anglera, wykonana została wspomnianym wyżej radełkiem składającym się z czterech głów wielkich reformatorów religijnych w medalionach, każdorazowo określonych identyfikującymi ich napisami w otoku: MARTI LUTHE - PHILIP MELAN - JOANES HVS 1415 - ERASMVS ROTRODAM ${ }^{68}$. Centralne pole zwierciadła górnej okładziny wypełnia równolegle obok siebie odciśnięte podwójnie radełko z motywem żołędzia w rysunku. Dolna okładzina posiada dekorację identyczną jak górna. Relief dekoracji obu okładzin jest stosunkowo płytki, niekiedy wytarty zupełnie, dzięki czemu rysunki przedstawień

67 E. Kuhnert, dz. cyt.,, s. 269-276; K. Haebler, Rollen- und Plattenstempel des XVI. Jahrhunderts, (Sammlung Bibliothekswissenschaftlicher Arbeiten, H. 41), Leipzig 1928 (edycja faksymilowa Martino Publisching 2008), s. 13-18; M. Komorowski, Die Erforschung der Königsberger Buch- und Bibliotheksgeschichte, [in:] Kulturgeschichte Ostpreussens in der Frühen Neuzeit, Hrsg. K. Garber, M. Komorowski, A.E. Walter, Tübingen 2001, s. 169; F.A. Schmidt-Künsemüller, Angler, Caspar, [in:] Lexikon des gesamten Buchwesens Online, [online] http://dx.doi.org/10.1163/ 9789004337862_lgbo_COM_010625 (dostęp 4. 02. 2021).

68 E. Kuhnert, dz. cyt., s. 276; K. Haebler, dz. cyt., s. 14, poz. 24; reprodukują ją J. Tondel. A. Wagner, The Silver Library..., s. 38. 
są słabo czytelne. Oprawa zaopatrzona była w dwie klamry, z których do dziś zachowały się jedynie zapinki na górnej okładzinie.

Należy uznać olsztyński egzemplarz, jako zachowany w stosunkowo dobrej kondycji. Cały kodeks sprawia wrażenie solidnego, pozbawionego poważniejszych uszkodzeń, poza dolnym prawym marginesem spodniej okładziny, gdzie brak fragmentu lica skóry wraz z dekoracją, został naprawiony i uzupełniony. Lico skóry na obu okładzinach jest $\mathrm{w}$ wielu miejscach porysowane, niekiedy mocno wytarte, w niektórych miejscach zabrudzone. Blok książki połączony jest z oprawą za pomocą pięciu zwięzów. U szczytu i podstawy grzbietu introligator zastosował dwa dodatkowe garby, odpowiadające tzw. fałszywym zwięzom. Umocowanie jest trwałe. Skóra grzbietu książki - podobnie jak całość oprawy - jest w dość dobrej formie, pozbawiona jednakże zupełnie dekoracji. Grzbiet książki, zarówno u góry, jak i u dołu, na odcinku pomiędzy pierwszym a drugim garbem jest oderwany od górnej okładziny. W przestrzeni pomiędzy garbami pierwszym i drugim od dołu znajdują się resztki prawdopodobnie dwóch sygnatur, jednej wymalowanej na skórze, drugiej naklejonej. Wszystko to przykryte jest współczesną nalepką z sygnaturą biblioteki seminaryjnej w Olsztynie. Niestety karty tomu w znacznej części (ok. 80\%) są zaplamione oraz noszą liczne ślady zalania, zwłaszcza na wewnętrznych i zewnętrznych marginesach, a co najistotniejsze, na części z nich rozwinęły się drobnoustroje (grzyby), które jednak dzisiaj wydają się już zneutralizowane i nieaktywne. Szereg kart, włącznie z kartą frontyspisową, jest postrzępionych, zwłaszcza u dołu. Kodeks posiada bardzo nieliczne ślady działalności drewnojada, ale dotyczy to jedynie dolnej okładziny i przylegających doń kilkunastu kart. Mimo tych mankamentów większość kart pozostaje w dobrej kondycji. Pomimo zalań i upływu czasu nie uległy deformacji i tylko nieliczne mają drobne uszkodzenia mechaniczne (rozdarcia). Kodeks nie był poddawany zabiegom konserwatorskim poza wspomnianą naprawą dolnej okładki, ale zabiegu tego dokonano raczej $\mathrm{w}$ warsztacie introligatorskim, aniżeli w pracowni konserwacji.

Mając za sobą kwestie proweniencyjne oraz szczegółowy opis egzemplarza, warto na koniec zastanowić się nad jego użytkowaniem w szeregu bibliotek, w jakich znajdował się w swojej blisko 500-letniej historii. Niestety sam kodeks dostarczy nam w tej materii bardzo niewiele dowodów. W zasadzie poza drobnymi uszkodzeniami oraz przetarciami okładzin, wolumin nie posiada zupełnie jakichkolwiek śladów świadczących o tym, iż był przedmiotem aktywności czytelniczej swoich poprzednich właścicieli i użytkowników. Karty naszego druku nie posiadają tak przecież charakterystycznych dla często wertowanych kodeksów zabrudzeń dolnych naroży, które w przypadku wielowiekowej historii książki są szczególnie widoczne. Jedynym - wspomnianym już - śladem świadczącym o kontakcie z czytelnikiem są przetarcia oprawy oraz naderwany grzbiet woluminu, który uszkodzono prawdopodobnie podczas wyciągania 
ciasno umieszczonej książki na półce. Trudno natomiast przypisać któremuś z czytelników nieostrożne obchodzenie się z książką, skutkiem czego uległa zalaniu. Plamy, z którymi mamy do czynienia w tym przypadku są ewidentnie spowodowane poważnym zalaniem kodeksu. Wydarzyło się to bez wątpienia nie przy biurku czytelniczym, a raczej w magazynie bądź miejscu składowania do którego dostała się woda. Możliwe, że jest to skutek niewystarczającego zabezpieczenia księgozbioru przed wilgocią podczas jego ewakuacji w czasie II wojny światowej.

Królewiecki egzemplarz pozbawiony jest także kompletnie typowych dla druków XVI stulecia klasycznych śladów lektury, a więc dowodów intelektualnego zainteresowania jego treścią. Jego poprzedni właściciele nie pozostawili po sobie często stosowanych podkreśleń tekstu, czy też tzw. rączek, a więc znaków wskazujących na szczególnie ciekawe jego fragmenty. Nie znajdziemy również w naszym woluminie ani jednego wyrazu komentarza, czy jakiejkolwiek zapiski marginalnej. Słowem, bacząc na pozostawione na nim tzw. vestigia lecturae można sądzić, że kodeks był użytkowany nieznacznie, by nie powiedzieć prawie w ogóle. Ale przecież vesaliańska Fabrica nie była wszakże książką przemilczaną. Przywołani na początku naszych rozważań amerykańscy uczeni oceniają, że ponad $2 / 3$ zachowanych woluminów zawiera szereg uwag i adnotacji, a także innych śladów aktywności czytelników, które dobitnie świadczą, że dzieło Vesaliusa było książką czytaną i komentowaną, choć analiza wielu egzemplarzy pokazuje, że komentarze generalnie raczej odnoszą się do wybranych partii tekstu, rzadko do całego dzieła ${ }^{69}$. Co zatem stało się w przypadku królewieckiego egzemplarza? Czy w czasie kilkusetletniej jego obecności w środowisku intelektualnym uniwersyteckiego miasta nie znalazł się nikt, kto zainteresował się jego treścią? Wydaje się, że tak kategorycznego sądu nie możemy wydać. Brak śladów lektury mógł mieć kilka przyczyn. Przede wszystkim należy odnotować, iż książka najprawdopodobniej nie należała do żadnego praktykującego lekarza, choć również i to nie przesądza o praktyce jej glosowania ${ }^{70}$. Obaj jej pierwsi właściciele nie byli medykami, zaś z chwilą kiedy wolumin znalazł się na półce Biblioteki Zamkowej, poczęły go chronić bibliotekarskie przepisy, które w przypadku biblioteki publicznej zabraniały ingerencji w materię książki. Wyraźny zakaz stosowania komentarzy oraz podkreślania partii tekstu spotykamy już w Leges

69 Fabrica Census, s. 56-59.

70 Jeśli wziąć dla przykładu znajdujący się obecnie w zbiorach Biblioteki Polskiej Akademii Nauk w Gdańsku, egzemplarz drugiego wydania Fabrica, którego posiadaczem był XVI-wieczny śląski lekarz Wenceslaus Raphanus, to przekonamy się, iż pomimo jego zaangażowania w praktykę lekarską oraz w zadania wynikające z funkcji lekarza (fizyka) miejskiego Opawy, właściciel ów również nie pozostawił na swym woluminie żadnych śladów lektury; zob. K. Nierzwicki, $W$ poszukiwaniu..., s. 196. 
Bibliothecae sformułowanych w $1578 \mathrm{r}$. przez - wielokrotnie tu przywoływanego - M. Scriniusa. W paragrafie X zapisał: Nihil intus scribito notam nullam, lineamve in folia ducito ${ }^{71}$. Niemal sto lat później (1673) kolejny z bibliotekarz M.S. Grabe, układając nowe przepisy korzystania ze zbiorów, poświęcił aż dwa paragrafy, aby skutecznie przestrzec czytelników przed stosowaniem atramentu i niszczeniem książek: Quilibet libros usui sui commodatos reverenter tractato, neque atramento, rubrica, plumbagine maculato, aut plicationibus folium, sive quomodocunque oblaedito (par. VII) oraz: Excerpturi aliquid ex libris in privatum commodum, pugillaria adportanto; atramenti vero usus omnibus interdictus esto, quo et libri et stragulae a maculis praeserventur (par. VIII) ${ }^{72}$. To zapewne owe zapisy legły u podstaw - opisywanego przez monografistę tej biblioteki - stosowanego w Królewcu zwyczaju nieumieszczania aparatu glosatorskiego na czytanych książkach. Potwierdzeniem tego są liczne zachowane egzemplarze $\mathrm{w}$ Bibliotece Uniwersyteckiej w Toruniu, również pozbawione komentarzy. Dotyczy to także książek z prywatnej biblioteki Albrechta ${ }^{73}$. Zapewne książę dawał tym dobry przykład innym czytelnikom.

Stosunkowo nieznaczne wykorzystywanie naszego kodeksu mogło być spowodowane również faktem, iż stanowił on w pewnym sensie dublet do edycji z 1543 r., którą - o czym już była mowa - również przechowywano w bibliotece niemal od początku jej funkcjonowania. Co więcej, w zbiorach Biblioteki Zamkowej znajdował się także popularny skrót Fabrica - De humani corporis Fabrica librorum Epitome, zarówno w jednej z wielu edycji XVI w. - odnotowany jeszcze w katalogu Polyphema ${ }^{74}$, jak i w pięknym miedziorytniczym wydaniu amsterdamskim z $1642 \mathrm{r}^{75}$, które weszło do zbiorów wraz z darem ponad 500 książek generalnego namiestnika Prus Książęcych w latach 1657-1669 Bogusława Radziwiłła, co zostało odnotowane w wydrukowanym w tym celu katalogu, przygotowanym przez książęcego

71 W całości paragraf X (cyt. Za E. Kuhnert, dz. cyt., s. 82) brzmi: Librum ut Jllustrissimi Principis supellectilem reverenter et sine labe tractato: Nihil intus scribito notam nullam, lineamve in folia ducito. W tłumaczeniu: Niech z książka, jako własnościa Najjaśniejszego Księcia obchodzi się z szacunkiem i bez szkody: niech nie zapisuje wewnątrz żadnych uwag ani linii po kartach niech nie prowadzi; thumaczenie tekstu zawdzięczam filologicznej wiedzy Pani mgr Magdaleny Awianowicz, za co pragnę Jej serdecznie w tym miejscu podziękować.

72 Cyt. za E. Kuhnert, dz. cyt., s. 124; w thumaczeniu: Niech ktokolwiek, komu powierzono ksiązki do użytku, obchodzi się z nimi z szacunkiem, nie plami atramentem, czerwonym kolorem, ołówkiem, ani nie niszczy zaginaniem kart lub w jakikolwiek inny sposób.(par. VII) oraz: Niech ci, którzy zamierzaja wypisywać z książek cokolwiek na prywatny użytek, przynosza ze soba tabliczki do pisania; niech dla wszystkich zakazane będzie użcie atramentu, aby ksiażki i oprawy chronione byty przed plamami; w tym wypadku za tłumaczenie również dziękuję p. M. Awianowicz.

73 J. Tondel, Biblioteka Zamkowa ..., s. 158.

74 E. Kuhnert, dz. cyt., s. 29.

75 A. Vesalius, Librorum [...] de humani corporis fabrica epitome, cum annot. N. Fontani, Amstelodami, apud Jo. Janssonium, 1642. 
bibliotekarza M.S. Grabego ${ }^{76}$. O edycji Fabrica z 1725 r. już wspominano. Również i biblioteka miejska w Królewcu (Stadtbibliothek Königsberg), której podwaliny dał księgozbiór Johannesa Poliandra, otrzymała wraz z nim prace anatomiczne, chociaż bez wątpienia nie była to żadna $\mathrm{z}$ bazylejskich edycji Fabrica ${ }^{77}$.

Wróciwszy do rozważań o użytkowaniu analizowanego w niniejszym przyczynku egzemplarza Fabrica, z braku konkretnych przykładów, pozostaje nam jedynie wskazanie potencjalnych grup jego czytelników. W pierwszym rzędzie winniśmy skierować nasze zainteresowanie na wydział medyczny uniwersytetu królewieckiego, który funkcjonował od początku działalności Albertyny ${ }^{78}$. Przewinęło się przezeń wielu uczonych lekarzy i studentów, których wykonywany zawód lub edukacja winny były skłonić do lektury dzieła Vesaliusa. Generalnie trzeba przyjąć, że profesorowie medycyny i lekarze przyboczni księcia Albrechta byli grupą najbardziej predestynowaną do tego, aby uznać ich za pewnych użytkowników księgozbioru medycznego, w tym i omawianego woluminu Fabrica. Stwierdzenie to jest tym szczególniej uzasadnione, iż wśród nich znalazły się osoby o dużych walorach intelektualnych i talentach medycznych oraz zamiłowaniach do książki. Dość wspomnieć tutaj o XVI-wiecznych uczonych Johannesie Placotomusie, Andreasie Aurifabrze, Matthiasie Stojusie, czy też choćby o działającym w wieku XVII, głośnym chirurgu Danielu Schwabe, który zasłynął wykonaniem w 1635 r. udanej operacji wydobycia noża z żołądka służącego, który szczęśliwie przeżył ów zabieg, zaś nóż stał się nawet obiektem muzealnym ${ }^{79}$. Uczeni medycy byli też szczególnie uprzywilejowani, jeśli idzie o możliwości korzystania z księgozbioru zamkowego ${ }^{80}$. Podobnie ważnym środowiskiem wykorzystującym bibliotekę była brać studencka, stanowiąca najliczniejszą grupę czytelniczą. Do tego dochodzili uczeni i miłośnicy innych dziedzin, którzy mogli zainteresować się tym pięknym, a gdyby użyć terminologii współczesnej - można by rzec - albumowym wydawnictwem anatomicznym. Co więcej, wydawnictwem, które przejawiało również cechy publikacji o charakterze erotycznym. O zainteresowaniu traktatem Vesaliusa

76 Catalogus librorum quarumlibet facultatum a [...] Duce Boguslao Radziwil [...] Electorali, quae Regiomonti Borussorum est, Bibliothecae legato donatorum 1668, Regiomonti, typis Friderici Reusneri 1673, k. [4], poz. 44; E. Kuhnert, dz. cyt., s. 128.

77 Geschichte der Stadtbibliothek zu Königsberg..., s. 56, 62.

78 S. Jaster, Die medizinische Fakultät der Albertus-Universität und ihre bedeutendsten Vertreter im 16. Und 17. Jahrhundert, [in:] Die Universität Königsberg..., s. [42]; w polskiej literaturze o tym wydziale zob. A. Skrobacki, Polacy na wydziale lekarskim Uniwersytetu w Królewcu, Olsztyn 1969.

79 S. Sokół, Medycyna w Gdańsku w dobie Odrodzenia, Wrocław 1960, (Monografie z Dziejów Nauki i Techniki, XIV), s. 108-109; inne nazwisko (Georg Lothus) w kontekście tego wydarzenia przytacza Jerzy Serczyk, zob. J. Serczyk, Albertyna. Uniwersytet w Królewcu, Olsztyn 1994, s. 45.

80 J. Tondel, Biblioteka Zamkowa ..., s. 153. 
również i pod takim kątem wspominają cytowani wielokrotnie amerykańscy autorzy światowego spisu dwóch pierwszych wydañ ${ }^{81}$.

Niezależnie od powodów czytelniczych fascynacji tym wybitnym zarówno od strony edytorskiej, jak i naukowej dziełem, warto podkreślić, że jego obecność w Królewcu na tamtejszym uniwersytecie i to przynajmniej w trzech egzemplarzach, jest doskonałą egzemplifikacją opinii Jerzego Serczyka, iż surowy sąd pod adresem królewieckiej Albertyny Henryka Barycza, sprowadzający się do konkluzji, jakoby uniwersytet ów był zacofany pod względem naukowym, koncentrujący swoją aktywność na realizowaniu celów ideologicznych i politycznych, nie do końca był uprawniony ${ }^{82}$. Obecność w Królewcu wspaniałych, bogato wyposażonych bibliotek, w których znajdowała się znacząca część dostarczanych na bieżąco - jak w przypadku egzemplarzy Fabrica $^{83}$ - wytworów intelektualnych europejskiej nauki jest tego ewidentnym potwierdzeniem.

Fot. 1. A. Vesalius, De humani corporis fabrica ..., Basel 1555, Źródło: BWSDMW „Hosianum” Sd. 670, oprawa, górna okładzina, Zdjęcie: K. Nierzwicki

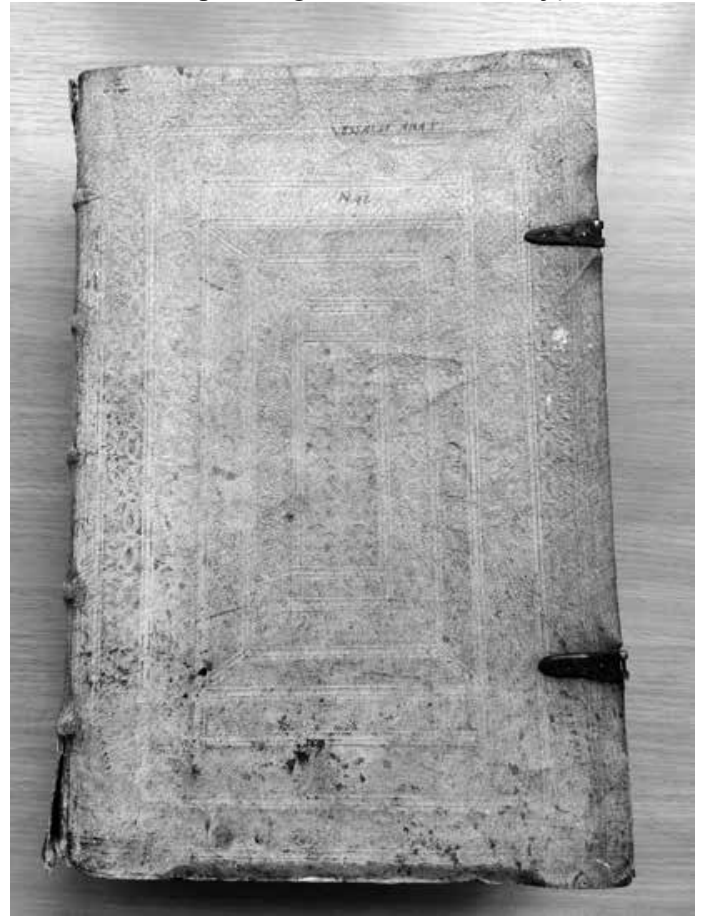

81 Piszą o tym w wielu miejscach w rozdziale: Reading and Annotating the Fabrica: The Sporadic Reader, zob. Fabrica Census, s. 56-120.

82 J. Serczyk, Albertyna..., s. 8-9.

83 Tak było w przypadku obu bazylejskich edycji Fabrica, które dotarły do Królewca niemal zaraz po ich wydrukowaniu. 
Fot. 2. A. Vesalius, De humani corporis fabrica ..., Basel 1555, Źródło: BWSDMW „Hosianum” Sd. 670, karta tytułowa, Zdjęcie: K. Nierzwicki

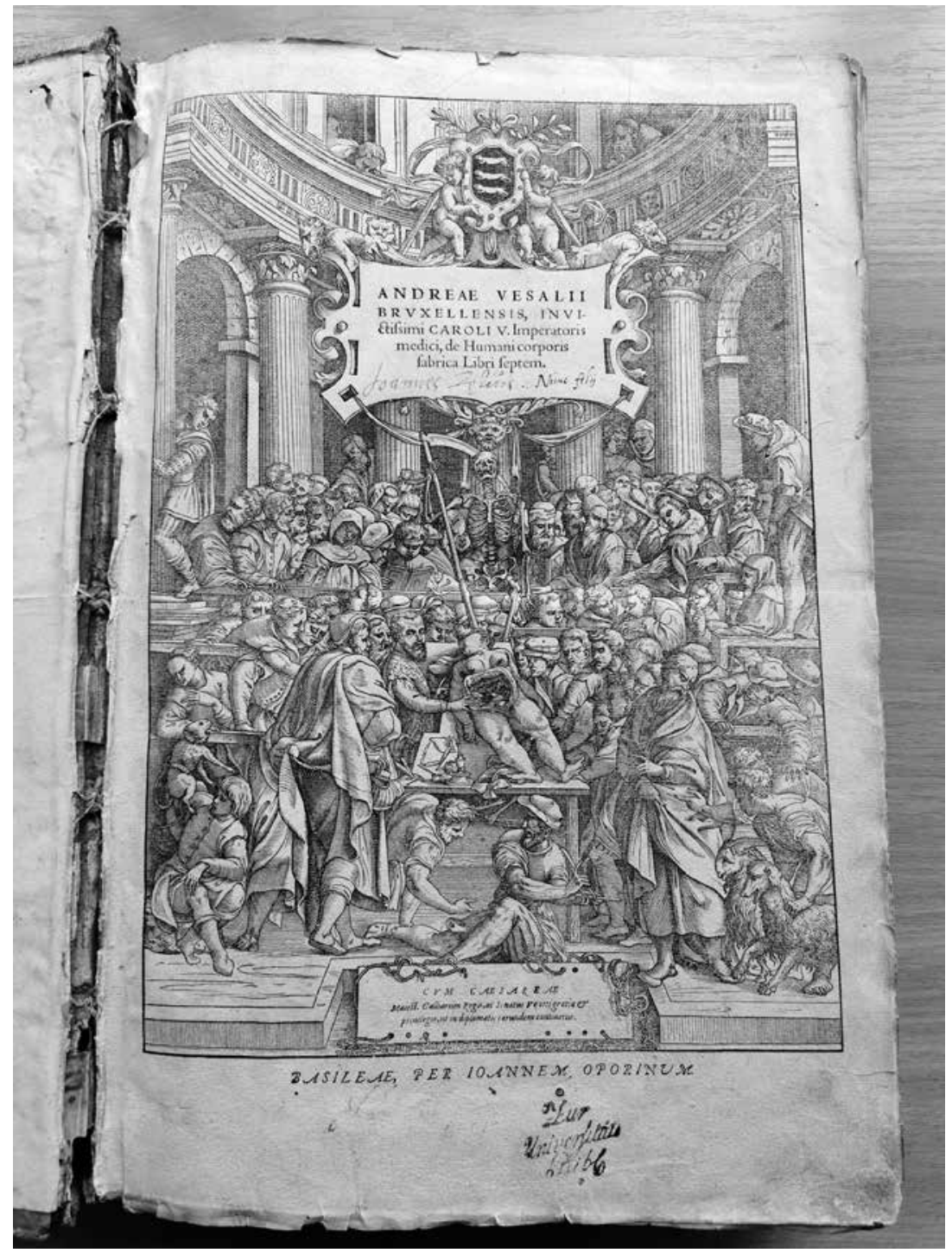


Fot. 3. A. Vesalius, De humani corporis fabrica ..., Basel 1555, Źródło: BWSDMW „Hosianum” Sd. 670, karta tytułowa, zapiska własnościowa Johannesa Zella i syna, Zdjęcie: K. Nierzwicki

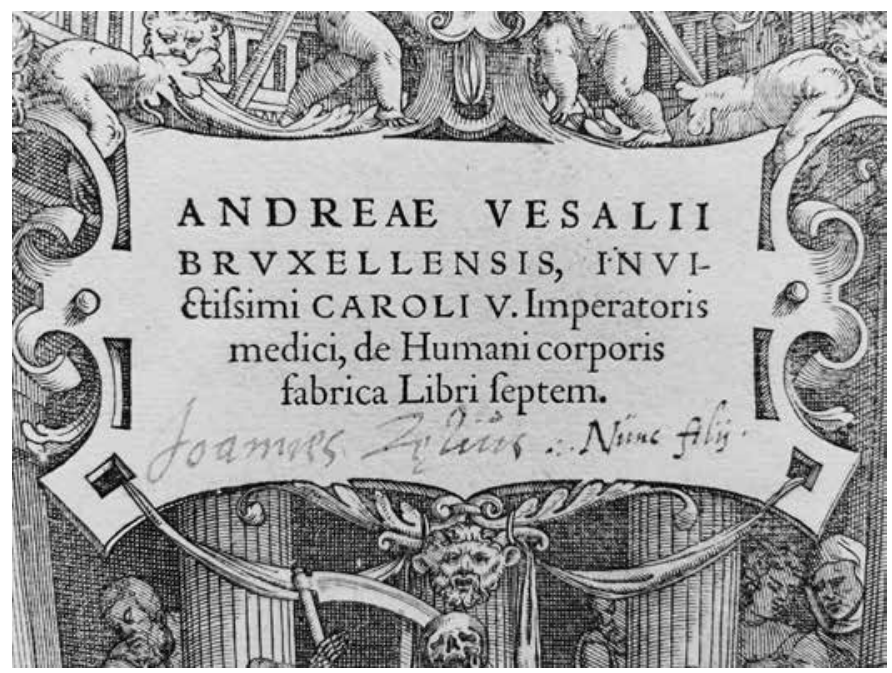

Fot. 4. A. Vesalius, De humani corporis fabrica ..., Basel 1555, Źródło: BWSDMW „Hosianum” Sd. 670, fragment oprawy z sygnaturą Michaela Scriniusa, Zdjęcie: K. Nierzwicki

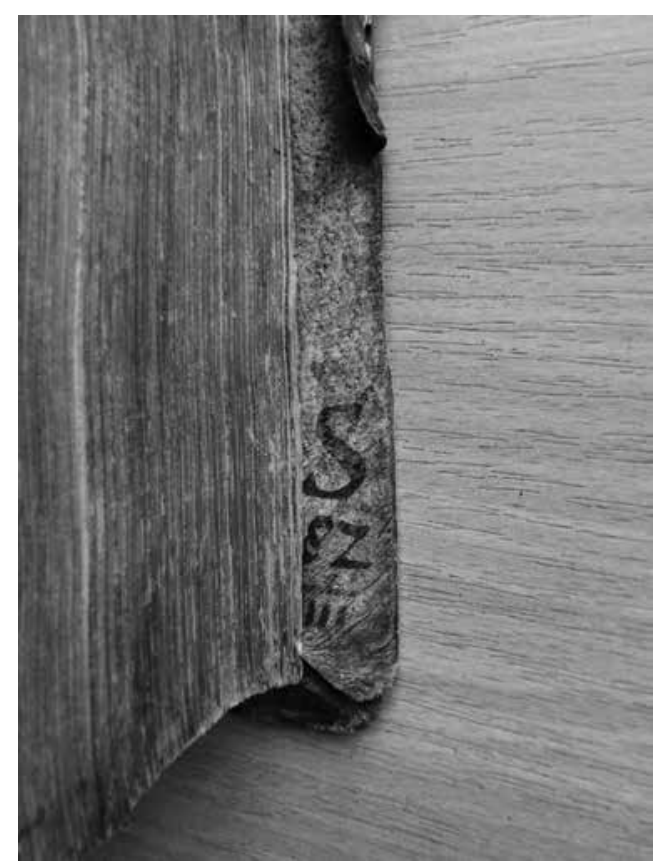


Fot. 5. A. Vesalius, De humani corporis fabrica..., Basel 1555, Źródło: BWSDMW „Hosianum” Sd. 670, odwrocie karty tytułowej, pieczęcie Biblioteki Zamkowej w Królewcu i Biblioteki Wyższego Seminarium Duchownego w Olsztynie, Zdjęcie: K. Nierzwicki

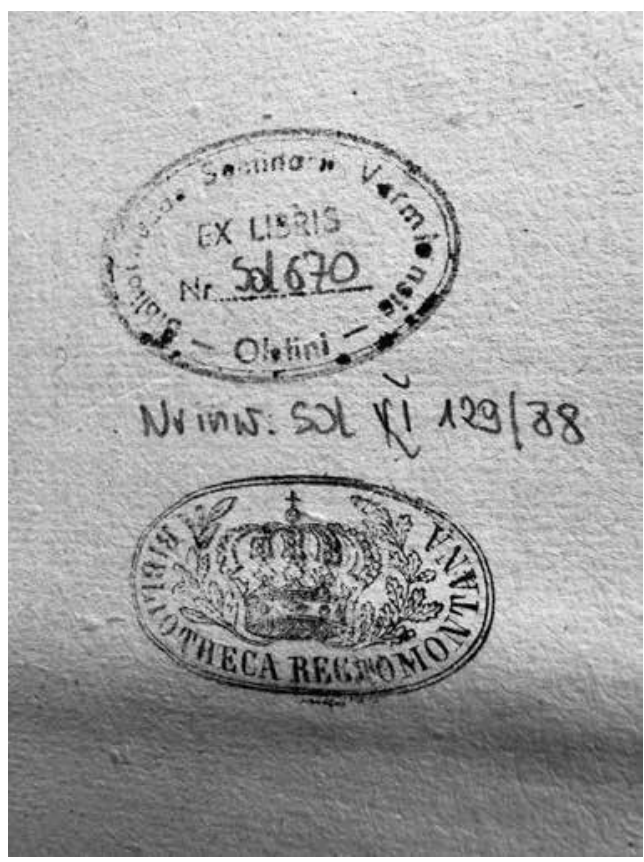

Fot. 6. A. Vesalius, De humani corporis fabrica..., Basel 1555, Źródło: BWSDMW „Hosianum“ Sd. 670, fragment wyklejki górnej okładziny, sygnatura Biblioteki Zamkowej z 1809 r., Zdjęcie: K. Nierzwicki

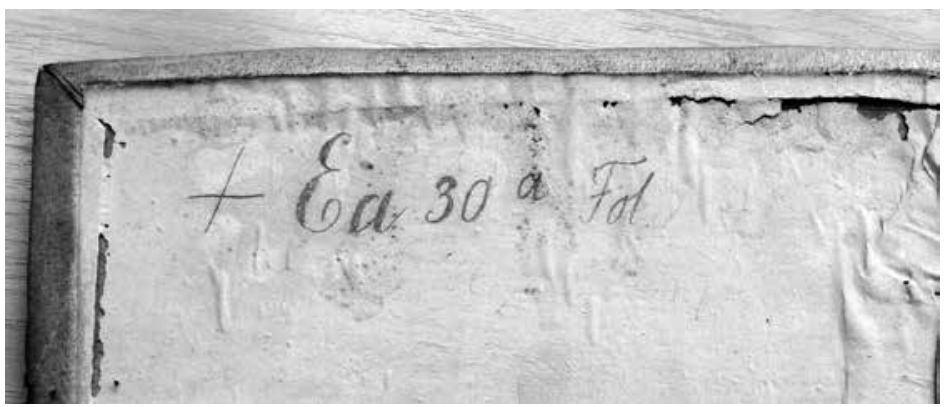


Fot. 7. A. Vesalius, De humani corporis fabrica ..., Basel 1555, Źródło: BWSDMW „Hosianum” Sd. 670, fragment karty tytułowej z pieczęcią Biblioteki Uniwersyteckiej w Królewcu, Zdjęcie: K. Nierzwicki

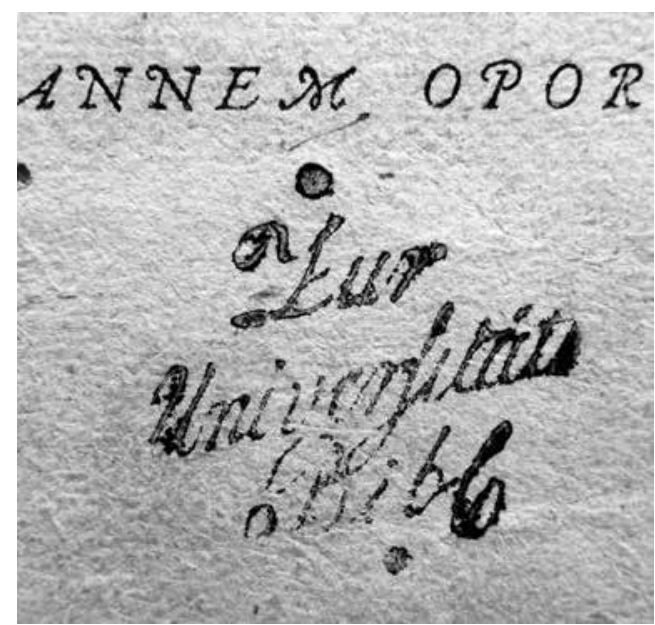

Bibliografia

Starodruki

Grabe, M.S., Catalogus librorum quarumlibet facultatum a [...] Duce Boguslao Radziwil [...] Electorali, quae Regiomonti Borussorum est, Bibliothecae legato donatorum 1668, Regiomonti, typis Friderici Reusneri 1673.

Roterodamus E., Adagiorvm D. Erasmi Roterodami epitome. Ex nouissima chiliadum recognitione excerpta, Antwerpiae, Ex officina Christophori Plantini, 1564.

Theophanes Nonnus, Noni Medici Clarissimi De omnivm Particvlarivm Morborvm Cvratione, sic ut Febres quoque [et] Tumores proter naturam complectatur, Liber..., Argentorati, Excudebat Iosias Rihelius, 1568.

Vesalius A., De Humani Corporis Fabrica Libri septem, Basileae, ex officina Joannis Oporini, 1543.

Vesalius A., De Humani Corporis Fabrica Libri Septem, Basileae, ex officina Joannis Oporini, 1555.

Vesalius A., Librorum [...] de humani corporis fabrica epitome, cum annot. N. Fontani, Amstelodami, apud Jo. Janssonium, 1642.

Vesalius A., Opera omnia anatomica \& chirurgica. Cura Hermanni Boerhaave \& Bernhardi Siegfried Albini, Lugduni Batavorum, apud Joannem du Vivie at Joan. \& Herm. Verbeek, 1725. 
Literatura

Aeltere Universitäts-Matrikeln. I. Universität Frankfurt a. O., Hrsg. E. Friedländer; Mitw. G.H.T. Liebe, E. Theuner, Leipzig 1887, Publicationen aus den K. Preußischen Staatsarchiven, Bd. 1.

Anselmino Th., Medizin und Pharmazie am Hofe Herzog Albrechts von Preußen (14901568), Heidelberg 2003.

Bikauskienė D., Bliūdžiūtė O., Drucke Königsberger Provenienz in der Akademiebibliothek Vilnius - Das 16. Jahrhundert, [in:] Königsberger Buch- und Bibliotheksgeschichte, Hrsg. A.E. Walter, Köln 2004, s. [519]-546.

Burhardt S., Historia pierwszego pięciolecia Biblioteki UMK, „Studia o Działalności i Zbiorach Biblioteki Uniwersytetu Mikołaja Kopernika” cz. III, Toruń 1987, s. 7-31.

Burmeister K.H., Der Kartograph Heinrich Zell (1518-1564), [in:] Science and history. Studies in honor of Edward Rosen, Wrocław 1978, Studia Copernicana 16, s. [427]-442.

Catalogus librorum qui conseruantur in Bibliotheca Ecclesiae parochialis veteris urbis Regiomontanae ex Testamente Reuerend: D. Joannis Poliandri vel Grauman Anno 1560 conscriptus ab illustriss. Principis Alberti Borussorum Ducis bibliothecario Henricho Zellio Agrippinate, [in:] Geschichte der Stadtbibliothek zu Königsberg. Mit einem Anhang Katalog der Bibliothek des M. Johannes Poliander 1560, Hrsg. Ch. Krollmann, Königsberg 1929, s. 1-66.

Catalogus Librorum Sedecimo Saeculo Impressorum Bibliothecae Teleki-Bolyai Nóvum Forum Siculorum, red. M. Spielmann-Sebestyén, L. Balázs, H. Ambrus, O. Mesaros, (Biblioteca Județeană Mureş), Târgu Mureş 2001.

Chlebus E., Dwie oprawy Tomasza Krügera z księgozbioru elblaskiego patrycjusza Andrzeja Morenberga [w:] Dawnych ksiag niesyty. Tom studiów dedykowanych Profesorowi Januszowi Tondelowi na siedemdziesięciolecie urodzin, pod red. I. Imańskiej i A. Wagnera, Toruń 2016, s. 205-221.

Die Matrikel der Universität Heidelberg von 1386 bis 1662, Hrsg. G. Toepke, T. 2 15541662, Heidelberg 1886.

Die Matrikel der Universität Köln, Bearb. H. Keusen, Bd. 2 (1476-1559), Hanstein, Bonn 1919.

Die Matrikel und die Promotionsverzeichnisse der Albertus-Universität zu Königsberg $i$. Pr. 1544-1829. Bd. 1, Die Immatrikulationen von 1544-1656, Hrsg. G. Erler, Bd. I, Leipzig 1910.

Dück J., Geschichte des Kronstädter Gymnasiums. Eine Festgabe zur dritten Säcularfeier desselben, Krönstadt 1845.

Garwoliński T., 60. rocznica wznowienia powojennej działalności Biblioteki Hosianum w Olsztynie, „Fides. Biuletyn Bibliotek Kościelnych” nr 1-2 (28-29) (2009), s. [96]-115.

Garwoliński T., Charakterystyka zbioru druków z XVI wieku Biblioteki Wyższego Seminarium Duchownego Metropolii Warmińskiej „Hosianum” w Olsztynie, „Archiwa, Biblioteki i Muzea Kościelne”, 102 (2014), s. [45]-65. 
Garwoliński T., Druki medyczne z XVi XVI wieku w zbiorach Biblioteki Wyższego Seminarium Duchownego Metropolii Warmińskiej „Hosianum” w Olsztynie, „Forum Bibliotek Medycznych”, R. 10, 2017, nr 1(19), s. 252-281.

Garwoliński T., Dzieje Biblioteki „Hosianum” (Braniewo - Olsztyn: 1565-2008), „Fides. Biuletyn Bibliotek Kościelnych”, 1-2 (2008), s. [59]-72.

Garwoliński T., Powojenne dzieje Biblioteki Warmińskiego Seminarium Duchownego „Hosianum” w Olsztynie, [w:] Cor Dioecesis. 450 lat Warmińskiego Seminarium Duchownego „Hosianum” (1565-2015), red. A. Kopiczko, P. Rabczyński, Olsztyn 2015, s. 471-502.

Garwoliński T., Utracone i zachowane kościelne księgozbiory warmińskie od XVII do XX wieku, „Bibliotheca Nostra. Śląski Kwartalnik Naukowy”, 3 (2015), s. 116-135.

Geschichte der Stadtbibliothek zu Königsberg. Mit einem Anhang Katalog der Bibliothek des M. Johannes Poliander 1560, Hrsg. Ch. Krollmann, Königsberg 1929.

Haebler K., Rollen- und Plattenstempel des XVI. Jahrhunderts, (Sammlung Bibliothekswissenschaftlicher Arbeiten, H. 41), Leipzig 1928 (Martino Publisching 2008).

Helwig H., Handbuch der Einbandkunde, Bd. 2, Hamburg: Maximilian-Gesellschaft, 1954.

Jaster S., Die medizinische Fakultät der Albertus-Universität und ihre bedeutendsten Vertreter im 16. Und 17. Jahrhundert, [in:] Die Universität Königsberg in der Frühen Neuzeit, Hrsg. H. Marti, M. Komorowski, Köln 2008, s. [42]-76.

Kolb A., Der Kartograph Heinrich Zell. Ein unbekannter Strassburger Drucker des 16. Jahrhunderts, „Gutenberg-Jahrbuch” 1972, s. 174-177.

Köln und Bonn mit ihren Umgebungen. Für Fremde und Einheimische. Aus den besten, und vorzüglich aus noch unbenutzten Quellen bearbeitet. Mit einem Grundrisse von Köln, Köln 1828.

Komorowski M., Das Schicksal der Staats- und Universitätsbibliothek Königsberg, „Bibliothek. Forschung und Praxis”, R. 4 (1980), s. 139-154.

Komorowski M., Die Erforschung der Königsberger Buch- und Bibliotheksgeschichte, [in:] Kulturgeschichte Ostpreussens in der Frühen Neuzeit, Hrsg. K. Garber, M. Komorowski, A.E. Walter, Tübingen 2001, s. 153-184.

Kuhnert E., Geschichte der Staats- und Universitätsbibliothek zu Königsberg. Von ihre Begründung bis zum Jahre 1810, Leipzig 1926.

Liceul Honterus. Anuar 2015/2016, red. H. Wagner, Braşov 2016.

Margócsy D., Somos M., Joffe S. N., The Fabrica of Andreas Vesalius. A Worldwide Descriptive Census, Ownership, and Annotations oft he 1543 and 1555 editions, Leiden, Boston, 2018, Medieval and Early Modern Philosophy and Science, vol. 28.

Marti H., Die Quellenbestände zur frühneuzeitlichen Königsberger Universitätsgeschichte im polnischen Olsztyn (Allenstein). Ein erster fragmentarischer Überblick, [in:] Königsberger Buch- und Bibliotheksgeschichte, Hrsg. A.E. Walter, Köln 2004, s. [571]-582.

Merlo J.J., Die Meister der altkölnischen Malerschule, Köln 1852. 
Merlo J.J., Ulrich Zell Koelns erster Drucker, Bearb. O. Zaretzky, Koeln 1900.

Nierzwicki K., Chetmiński egzemplarz „De humani corporis fabrica” Andreasa Vesaliusa (Bazylea 1555) w zbiorach Biblioteki Uniwersyteckiej w Toruniu, [w:] W świecie bibliologii i informatologii. Księga dedykowana Profesor Bronisławie Woźniczce-Paruzel $w$ 70. rocznice urodzin, Toruń 2019, s. [59]-98.

Nierzwicki K., W poszukiwaniu anatomicznego traktatu De humani corporis Fabrica Andreasa Vesaliusa (Basel 1543, 1555) w Gdańsku, „Biblioteka” 2019, nr 23 (32), s. 167-207.

Nierzwicki K., Warszawski egzemplarz „De humani corporis fabrica” Andreasa Vesaliusa (Bazylea 1555) ze zbiorów Biblioteki Narodowej. Przyczynek do dziejów recepcji anatomii wesaliańskiej w Polsce, [w:] Dawnych ksiag niesyty. Tom studiów dedykowanych Profesorowi Januszowi Tondelowi na siedemdziesięciolecie urodzin, pod red. I. Imańskiej i A. Wagnera, Toruń 2016, s. 167-203.

Nutton V., Historical introduction, [in:], Vesalius, The fabric of the human body : an annotated translation of the 1543 and 1555 editions, by Daniel H. Garrison, Malcolm H. Hast, Basel 2014, s. LXXV-CIII.

Obłąk J., Jaroszewicz-Pieresławcew Z., Wojtkowski J., Katalog inkunabułów Biblioteki Wyższego Seminarium Duchownego Metropolii Warmińskiej „Hosianum” w Olsztynie, Olsztyn 2007.

Oldfield Ph., Vesalius at 500, an exibition commemorating the five-hundredth anniversary oft he birth of Andreas Vesalius, Toronto 2014.

Reusch R., Harderwyk, Gerhard von, [in:] Allgemeine Deutsche Biographie 10 (1879), s. 593, [online] https://www.deutsche-biographie.de/pnd10096555 5.html\#adbcontent [dostęp 20.01.2021].

Schmidt-Künsemüller F. A., Angler, Caspar, [in:] Lexikon des gesamten Buchwesens Online, [online] http://dx.doi.org/10.1163/9789004337862_lgbo_COM_010625 [dostęp 4.02.2021].

Schullerus F., Siebenbürger Studirende (sic!) an der Universität Frankfurt an der Oder, [in:] „Archiv des Vereines für Siebenbürgische Landeskunde“, Neue Folge, Bd. 22, Hermannstadt 1889.

Serczyk J., Albertyna. Uniwersytet w Królewcu, Olsztyn 1994.

Serczyk J., Suche nach Büchern im ehemaligen Süd-Ostpreussen in den ersten Jahren nach dem Zweiten Weltkrieg. Erinnerungen eines polnischen Bibliothekars, [in:] Königsberger Buch- und Bibliotheksgeschichte, Hrsg. A.E. Walter, Köln 2004, s. [483]-494.

Sidorowicz-Mulak D., Wagner A., Dzieto Vesaliusa w oprawie Mistrza Dawida a problem początków księgozbioru króla Zygmunta Augusta, ,Roczniki Biblioteczne” 2015, R. 59, s. 3-24.

Skrobacki A., Polacy na wydziale lekarskim Uniwersytetu w Królewcu, Olsztyn 1969.

Sokół S., Medycyna w Gdańsku w dobie Odrodzenia, Wrocław 1960, (Monografie z Dziejów Nauki i Techniki, XIV). 
Strutyńska M., Alte Drucke Königsberger Provenienz in den Beständen der Universitätsbibliothek Toruń, [in:] Königsberger Buch- und Bibliotheksgeschichte, Hrsg. A.E. Walter, Köln 2004, s. [547]-562.

Strutyńska M., Struktura proweniencyjna zbioru starych druków Biblioteki Uniwersyteckiej w Toruniu. Przewodnik po zespołach. Problemy badawcze i metodologiczne, Torun 1999.

Szabó M., Tonk S., Erdélyiek egyetemjárása a korai újkorban 1521-1700, Szeged 1992, Fontes Rerum Scholasticarum, IV.

Thielen P.G., Ein Katalog der Kammerbibliothek Herzog Albrecht von Preussen aus dem Jahre 1576, „Jahrbuch der Albertus-Universität zu Königsberg Pr.“, Bd. IV, 1954, s. 202-226.

Tondel J., Biblioteka Zamkowa (1529-1568) księcia Albrechta Pruskiego w Królewcu, Toruń 1992.

Tondel J., Das Schicksal der Königsberger Schlossbibliothek, „Preussenland. Mitteilungen der Historischen Kommision für Ost- und Westpreussiche Landesforschung und aus den Archiven der Stiftung Preussischer Kulturbesitz" 1987, Jg. 25, s. 39-48.

Tondel J., Ekslibrisy Biblioteki Zamkowej Księcia Albrechta, [w:] tegoż, Ksią̇ka w dawnym Królewcu Pruskim, Toruń 2001, s. 264-276.

Tondel J., Eruditio et prudentia. Die Schloßbibliothek Herzog Albrechts von Preußen. Bestandkatalog 1540-1548, Wiesbaden 1998.

Tondel J., Katalog Poloników Kammerbibliothek i Nova Bibliotheca księcia Albrechta Pruskiego zachowanych w zbiorach Biblioteki Uniwersyteckiej w Toruniu, Torun 1991.

Tondel J., Królewiecki egzemplarz dzieła Mikołaja Kopernika „,De revolutionibus“ (Norymberga 1543) ze zbiorów Biblioteki Uniwersyteckiej w Toruniu, [w:] tegoż, Książka $w$ dawnym Królewcu Pruskim, Toruń 2001, s. 29-[50].

Tondel J., Księgozbiór królewieckiego lekarza Andrzeja Aurifabra (1513-1559), [w:] tegoż, Książka w dawnym Królewcu Pruskim, Toruń 2001, s. 51-129.

Tondel J., Wagner A., The Silver Library of Duke Albrecht of Prussia and his wife Anna Maria, Berlin 2019.

Verzeichnis der im deutschen Sprachbereich erschienenen Drucke des 16. Jahrhunderts, t. 1-24, Stuttgart 1983-2000.

Walter A.E., Das Schicksal der Königsberger Archive und Bibliotheken. Eine Zwischenbilanz, [in:] Königsberger Buch- und Bibliotheksgeschichte, Hrsg. A.E. Walter, Köln 2004, s. [1]-68.

Walter A.E., Die Königsberger Universitätsbibliothek in der Frühen Neuzeit. Grundzüge ihrer Geschichte, bibliotheksgeschichtliche Quellen, Perspektiven der Forschung, [in:] Die Universität Königsberg in der Frühen Neuzeit, Hrsg. H. Marti, M. Komorowski, Köln 2008, s. [264]-305.

Wojtkowski J., Katalog druków XVI wieku Biblioteki Wyższego Seminarium Duchownego Metropolii Warmińskiej „Hosianum”w Olsztynie, Lublin 2012.

Wojtkowski J., Stare druki w Bibliotece Wyższego Seminarium Duchownego Metropolii Warmińskiej „Hosianum”, „Fides. Biuletyn Bibliotek Kościelnych”, nr 1-2 (28-29) (2009), s. [32]-45. 